\title{
Correlational and Differential Influence of Historical Cost and Current Cost Profits on the Operating Capabilities of the Firm
}

\author{
S. A. Effiong \\ Department of Accounting \\ Faculty of Management Sciences, University of Calabar \\ Calabar, Nigeria \\ Tel: +23-480-3711-5127Ｅ-mail: drsunnyeffi@yahoo.com \\ J. O. Udoayang (Correspondence author) \\ Department of Accounting \\ Faculty of Management Sciences, University of Calabar \\ Calabar, Nigeria \\ Tel: +23-480-3419-4911Ｅ-mail: josephudoayang@yahoo.com
}

\author{
A. I. Asuquo \\ Department of Accounting \\ Faculty of Management Sciences, University of Calabar \\ Calabar, Nigeria \\ Tel: +23-480-6646-8333 E-mail: drakabom3@yahoo.com
}

Received: October 27, 2010

Accepted: December 29, 2010

doi:10.5430/ijfr.v2n1p64

\begin{abstract}
The study investigated the correlation and differential influence of historical cost and current cost profits on the operating capabilities of the firm. The financial statements of thirty-one Nigerian Companies were surveyed and adjusted for effects of price changes using the Consumers' Price Index (CPI). Correlation influence between the historical cost profits on the operating ability of the firm was measured and established on one hand and that of current cost profit on the other hand. Differential impacts of the method of profit measurement on the operating capability of the firm was equally measured and established. The weighted value of students' distribution - $t$, HC reveals a correlation which is materially significant between profits and operating ability of the firm. Equally, the F-test result reveals substantial differential impacts of profits measured on historical and current cost bases on the operating ability of the firm during periods of rising prices. Companies interested in maintaining equal operational strength during periods of changing prices are to adopt appropriate basis of profit measurements commensurating the impacts of price changes for the sustenance and survival of the firm.
\end{abstract}

Keywords: Historical and current cost profits, Inflation trend, Differential values, Operating capabilities, Published financial statements.

\section{Introduction}

The depleting nature of the shareholders capital resulting from the eroding effect of the historical cost accounting principle has made government and companies to be more concerned about maintaining the operating capital of the firm. The historical cost concept of accounting has not provided for any feasible measures for reflecting the dynamic nature of business transactions, vis-à-vis changing prices.

Due to this deficiency, most users of accounts tend to make mental adjustments to figures in the historical cost accounts to allow for the effect of inflation on the values of transactions.

The existence of inflation and its persistent nature call for an alternative to the historical cost accounting method of 
profit reporting. One of the feasible alternatives to the historical cost accounting method is the current cost accounting method. Current cost accounting method has, as a basic principle, that operating profits should only be measured and reported after the capital of the firm has been maintained, (Dean, 1994). The emphasis on capital maintenance is highly imperative in today's business environment if the business must survive and succeed (Glautier and Underdown, 1998).

The capital of a business cannot be maintained in isolation of the principles, concepts and postulates employed in the measurement of the business income. As the income of the business directly affects the shareholders' capital, it therefore follows that the methods employed in measuring the income will equally directly influence the value of the shareholders' capital.

The basic problem with the historical cost method is that dividends, taxes and depreciation are based on profits measured by sales (which are at current values) less costs of sales and expenses measured on historical cost values, (Berliner, 1993). This measurement approach reduces the operating ability of the company's assets and does not maintain the capital of the firm.

To maintain the capital of the firm, current cost accounting (CCA) system makes use of the current cost of transactions in arriving at the profit of the firm. The Statement of Standard Accounting Practice (SSAP), (1991); states that current cost accounting was intended to provide management and shareholders with useful information about financial viability, returns on investment, pricing policy, cost control, distribution and gearing decisions.

Despite stipulations and regulations on inflationary trends, published financial statements in Nigeria have not made provisions to disclose the implications of price changes on the value of the balance sheet and on the value of transactions. The Federal Office of Statistics of Nigeria, between 1999 and 2005, gave fluctuating rates as inflation trend in Nigeria. As expected in the data, the inflation rates dropped from as high as $72.8 \%$ in 1995 to as low as $6.6 \%$ in 1999 and increased from there to $16.4 \%$ in 2004.

Thus, the need to have a meaningful profit measurement in the circumstance of the ever-increasing rate of inflation in our economy is pertinent now than ever. This need has thrown a great challenge on the accounting profession, governments and managements of businesses to effectively measure and report the operating capabilities of the assets and maintain the capital of the companies intact.

The concern of accountants and accounting bodies now is how to measure and report profits which will strengthen the capital of the firm even if inflation rate is persistently rising.

The historical cost principle, which is the traditional accounting reporting method, is grossly inadequate in periods of rising prices. The problem with this method is that selling prices are stated in current prices while costs of the assets used in generating sales are stated in historical costs, that is, acquisition costs. This approach results in overstated profit leading to overpayment of taxes and dividends. Equally, fixed assets and stocks of goods face the same problem. The conventional practice is to record fixed assets at their acquisition costs throughout their useful life. Depreciation is also charged based on the acquisition cost of the asset irrespective of the current replacement cost of such asset.

\section{Theoretical Framework}

The objective of financial reporting to investors is found in the decision which the investors have to make about their investments. Investors are primarily concerned with the worth of their investment in two ways. One, they are concerned with maintaining and increasing the value of their capital. Two, they are concerned with maintaining and increasing the income which is derived from the capital.

Financial reports are called to question in periods of rising prices of goods and services. This is because the value of assets carried in the books of the company does not bear true figure to the operating ability of the company.

During this period, profits measured on historical cost basis are overstated and capital depleted. The operating capability of the firm must be maintained by applying the capital and other value maintenance theories.

\subsection{Capital Maintenance Theory}

Capital maintenance theory is viewed in three perspectives. These include financial capital maintenance, general purchasing power maintenance and physical capital maintenance.

The financial capital maintenance concept is seen by Salvary (2004) as an increase in the number of nominal Naira representing capital. The historical cost nominal Naira method of accounting is a financial capital maintenance approach because revenues must exceed historical costs before income can be reported.

Equally, Kistner and Salmi (1980) consider the historical cost/constant Naira method as being based on the general purchasing power capital maintenance concept. In this concept, income is the excess of capital at the end of the period 
over the capital at the beginning, both expressed in terms of constant general purchasing power of Naira. Accordingly, restatement of non-monetary assets and liabilities are not included in income, but the purchasing power gains and losses on monetary items are included.

Hendrickson and Brenda (1992) explain the physical capital maintenance approach to mean the operating capability of the company. In this approach, capital is maintained if the firm is able to replace its assets with assets of the same type or if it is able to maintain the capacity to produce a constant supply of goods and services.

Firms, in this thinking may not necessarily replace specific assets or even continue to produce the same goods and services, but the use of current cost (or restatement by the use of specific index) may in the aggregate be an acceptable surrogate for the physical capacity purchasing power of the firm.

\subsection{Value Differential Theory}

The Value Differential Theory classifies accounting values into two basic types. These include the sacrifice value and the benefit value. Ijiri (1997), sees the sacrifice values to be equivalent to the historical cost or replacement cost and represent the amount of disunity or sacrifice necessary to obtain economic goods and services.

Benefit values, such as selling prices, net realizable value or discounted present value, represent the utility or benefits obtainable from consuming goods and services.

Income measurements are based on the difference between two accounting values. These income measurements are simply referred to as value differentials. Historical cost income is based on a benefit-sacrifice differential, since it is measured by the difference between realized selling prices, which are benefit values, and historical costs, which are sacrifice values.

Accounting income is based on benefit differentials since, under this system of accounting, income is the difference between the net realizable value of net assets at the end and beginning of the accounting periods. Replacement cost income is composed of two types of differentials where holding gains are included in income. Operating profit, the difference between realized selling prices and replacement costs, is a benefit-sacrifice differential, whereas the holding gain on assets held during the period is a sacrifice differential since it is the difference between two replacement costs.

The basic objective of economic activity is to maximize the difference between benefits and sacrifices. A benefit-sacrifice differential is regarded as income because it indicates that the basic objective has been accomplished. Benefit differential also can be regarded as income because they indicate improvement or progress toward the basic economic objective. A positive benefit differential means that the expected benefits obtainable from the resources of the enterprise have increased.

\subsection{The Capital Adjustment Theory}

The underlying support for Capital Adjustment treatment comes from defining income as an amount that could be distributed while keeping intact the physical capital of the enterprise. This assertion assumes that management intends to replace physical capital and that owners view the firm as a going concern. Assuming replacement of asset and continuity of the firm is consistent with the choice of replacement costs of valuing the firm's assets, then income is consistently defined in terms of the maintenance of physical capital.

The capital adjustment treatment has some appeal where accounting profit is viewed as a surrogate for economic income. Economic income is based on the maintenance of capital in the sense of its cash generating potentials. Since direct measurement of cost generating potentials is impracticable, alternative accounting concepts of capital may be substantial if they correlate well with 'cash generating potentials'.

Physical capital or 'operating capability; may be viewed as reasonable surrogate for cash-generating potential. The level of future cash flows relate to the physical capacity of the firm's assets, or the quantity of output, which the firm is capable of producing.

Physical capital is not a perfect surrogate for cash generating potential, obviously. Future cash flows also depend upon the values of future output. It is quite possible that a lower level of physical capital could sustain the same level of cash flows if the value of the output were to rise sufficiently in future periods. Nevertheless, there is probably a fairly high correlation between the expected cash flows of future periods and the firm's operating capability at the present time (Bromwick, 1995; Barton, 1994).

The FASB is critical of the capital adjustment treatment for denying the possibility that earnings can be increased by the wise timing of purchases of assets for use by the enterprise.

\section{Methodology}


The study investigated the differences in impacts as well as correlational effects of profits measured on historical cost basis on one hand and those measurement on current cost basis on the other hand on the operating capabilities of companies.

Financial statements of companies quoted in the first tier securities market of the Nigerian Stock Exchange were used for the analysis. These were companies whose share prices are directly determined and influenced by the values and quality of assets used in their daily operations.

The study investigated thirty-one (31) companies under seventeen industrial classifications. These companies published their Annual Reports and Accounts for public consumption and have paid taxes and dividends up to 2005. Financial Statements of these companies published in 2001 were used as the basis for analysis. The base year of 2001 was chosen because the International Financial Reporting Standards (IFRS), (2004) requires that accounts of companies should be adjusted for effects of price changes when the country is experiencing inflation rate of 16 percent and above. The inflation rate in the 2001 was 18.9 percent and it was this year Nigerian government expressed genuine intention to curb inflation rate to a single digit.

Historical Financial Statements were adjusted for effects of price level changes using the Consumers' Price Index (CPI) for 2001. Previous studies by Peterson (1997) and Baran (1996) indicated that the CPI is a reliable deflator in the restatement procedure. Davidon, Stickney and Weil (1996) equally used CPI in adjusting the historical financial statements for effects of price changes in a study carried out in United Kingdom.

The Nigerian Companies investigated include Livestock Feeds Plc, Dunlop Plc, Afribank Plc, EIB International Plc, FSB International Plc, Hall Mark Bank Plc, Lion Bank Plc, Standard Trust Plc, Union Bank Plc, 7-up Plc, Niger Flour Mills Plc, P. S. Mandrid Plc, Glaxo-Smithlime Plc, Morison Industry Plc, First Aluminium Plc, Confidence Insurance Plc, Lasaco Plc, Niger Insurance Plc, Security Assurance Plc, Guinness Plc, Nigerian Wire Co. Plc, CAP Plc, AG Leventis Plc, PZ Plc, Unilever Plc, Julius Berger Plc, C \& I Leasing Plc, Avon Crown Caps Plc, Conoil Plc, Taxaco Plc and Longman Press Plc.

The study surveyed historical cost financial statements adjusted to current cost financial statements to evaluate the extent to which inflation undermines the operating abilities of these companies. These companies were selected on the assumption that they cover the broad spectrum of the largest significant portion of the Nigerian economic output and the financial statements of these companies considered the most viable and reliable measurement of financial strength and operational capabilities of the companies.

Historical cost financial statements deplete capital through excess taxes, dividends and lesser amount of depreciation (which is based on a very old value of assets); dividends were seen as the most objective yardstick in identifying the target population of the study. This is because all companies depreciate their assets and pay, at least, minimum taxes. But not all companies pay dividends regularly. Companies paying dividends are seen as those who are likely to pay out shareholders' capital as dividends because of the disguised 'huge profit' reported by the historical cost accounting system.

The paper approached the study by identifying companies which have paid dividends between 2001 and 2005 . The justification of the base year was therefore to examine how the reported inflation in that year influenced the operating capabilities of the companies.

The historical cost financial statements of these companies were adjusted to current cost data to measure the degree of the correlation of historical cost and current cost profits with the operating capabilities of the companies, on one hand, and the extent of the disparity between the historical cost and current cost profits on the operating capabilities on the other hand.

General Price Level (GPL) financial statements were developed from the historical cost data using the CPI published by the Federal Office of Statistics. The GPL adjustments were made in accordance with FASB Exposure Draft, with three exceptions from the financial capital maintenance concept. The three exceptions all dealt with the ways of maintaining the financial capabilities of the firm.

The Financial Capital Maintenance (FCM) method excludes the cost of sales adjustment (COSA), Monetary Working Capital Adjustment (MWCA) and Gearing Adjustment (GA). The FCM method prescribes only supplementary depreciation on the adjusted values of the assets for the purpose of maintaining the financial capabilities of the firm.

\section{Results}

Two hypotheses were developed and tested for the purpose of establishing the degree of correlation and differential influence of the historical and current cost profits on the operating capabilities of the firms. The operating capability of 
the firm is effectively represented by the operating capital of the firm.

Hypothesis one considers the differential influence of historical cost and current cost profits on the operating capital of the firm.

The ANOVA model of one-way classification test was used in testing this hypothesis. This model is given as:

$$
\mathrm{F}=\underline{\mathrm{M}}_{\underline{\mathrm{B}}}
$$

Where:

$\mathrm{F}=$ Fisher's Statistic of historical and current cost profits on the operating capabilities of the firms.

$\mathrm{M}_{\mathrm{SB}}=$ Mean sum of square variance between profits measured on historical cost basis and those measured on current cost basis on the operating capabilities of the companies.

$\mathrm{M}_{\mathrm{SW}}=$ Mean sum of square variance within profits measured on historical cost basis and those measured on current cost basis on the operating capabilities of the companies.

$$
\mathrm{MS}_{\mathrm{B}}=\frac{\mathrm{SS}_{\mathrm{B}}}{\mathrm{K}-1}
$$

Where:

$$
\begin{aligned}
& \mathrm{SS}_{\mathrm{B}}=\text { Sum of square variance between the historical cost sample and current cost sample on the operating } \\
& \text { capabilities of the companies. } \\
& \mathrm{K}=\text { Number of samples } \\
& \mathrm{MS}_{\mathrm{W}}=\underline{\mathrm{SS}}_{\mathrm{W}} \\
& \quad \mathrm{N}-\mathrm{k}
\end{aligned}
$$

Where:

$$
\begin{aligned}
& \mathrm{SS}_{\mathrm{W}}=\text { Sum of square variance within the historical and current cost samples on the operating capabilities of } \\
& \text { the companies. } \\
& \mathrm{N}=\text { Sample size }
\end{aligned}
$$

The values of the operating capital were obtained for the thirty-one companies. Equally, the historical cost profits and the current cost profits were obtained for all the studied companies. The mean score for the three samples was computed and data generated from this process subjected to a one-way analysis of variance test (ANOVA). The result of hypothesis one is presented in table 1 below.

The result of the analysis of variance shows F-value of 224, which is greater than the critical F-value of 2.99 at 0.05 level of significance with 2 and 90 degrees of freedom. This result is materially significant at this point.

This means that the accounting basis adopted by the company to measure the profits will influence differently on the operating capital of the firm than when a different basis is adopted in measuring the same profits. The null hypothesis is thus rejected and the alternative upheld, confirming that differential influences are significant on the operating capabilities of the firm where profits are measured on historical cost or current cost bases of profit measurement.

Hypothesis two considers the correlational association between profits and profits related variables on the operating capital of the companies.

The ordinary least square regression model was used in estimating the extent to which depreciation, taxes and dividends paid out of profits influence the operating capital of the firm. This model is stated below:

$$
Y_{t}=\mathrm{ao}_{\mathrm{c}}+\mathrm{b}_{1} D E P_{t}+\mathrm{b}_{2} \text { TAX }+\mathrm{b}_{3} D I V_{t}+\varepsilon
$$

Where:

$$
\begin{array}{lll}
\mathrm{t} & = & \text { The time period under consideration } \\
Y & = & \text { Operating capital of the firm } \\
\mathrm{ao}_{\mathrm{c}}= & \text { Estimated intercept of } \mathrm{c} \\
\mathrm{b}_{1} \ldots \mathrm{b}_{3}= & \text { Accounting betas of the independent variables } \\
D E P_{t}= & \text { The vector of depreciation variables }
\end{array}
$$




$$
\begin{array}{lll}
T A X_{t} & = & \text { The vector of tax variable } \\
D I V_{t} & = & \text { The vector of dividend variable } \\
\varepsilon & - & \text { Stochastic individualistic component of } Y_{\mathrm{t}}
\end{array}
$$

To test this hypothesis, the historical values for depreciation, taxes and dividends were extracted from the financial statement of the thirty-one companies under study together with their operating capital. The historical financial statements were converted to current cost financial statements and the current values for depreciation, taxes and dividends computed together with current values of their operating capital. The data obtained from this process were fitted into the ordinary least square regression estimator of multiple influences for both the historical and current cost values. The result of the test is presented in table two below.

The co-efficient of correlation (r) obtained from the result for the historical cost values was 0.91 . This value was tested for significance using the student t-distribution test of significance. Equally, the co-efficient of correlation (r) for the current cost values was 0.72 . This was equally tested for significance. The weighted co-efficient of correlation $\left(\mathrm{r}^{\mathrm{HC}}\right)$ was computed and the value of 0.82 was obtained. The value of $\mathrm{r}^{\mathrm{HC}}$ was tested for significance at 0.05 levels at 60 degree of freedom.

The historical t-value calculated was 29.12 while the critical value at 0,05 significance for 29 degree of freedom was 1.96. The current cost $t$-value at 0.05 significance for 29 degree of freedom was 13.04 while the critical value was 1.96 . The $\mathrm{t}$-value calculated for the weighted co-efficient of correlation $\left(\mathrm{r}^{\mathrm{HC}}\right)$ was 26.77 while the critical value at 0.05 significance for 60 degree of freedom was 1.96.

The calculated t-value for the historical cost set of data was found to be greater than the critical value. Hence, the result was significant. In the same way, the calculated t-value for the current cost data was found to be greater than the critical value. The result was equally significant. The calculated weighted $\mathrm{r}^{\mathrm{HC}}$ t-value was found to be greater than the critical value. The result put together, was significant at

$$
\operatorname{tr}^{\mathrm{HC}}=26.77 \text { at } 60 . \mathrm{P}<0.05=1.96
$$

\section{Conclusion}

The operating ability of the firm is significantly influenced by the reported profit. In other words, the profits declared and distributed will, to a greater extent, increase or reduce the operating capabilities and operational capacity of the firm.

The accounting basis adopted by the company at any given point in time exerts different influence on the reported profit and on the values of balance sheet items than when a different basis was used for the same period. That is to say that historical cost accounting method measures profits and the state of affairs of the company differently from when current cost accounting method is applied to measure the same thing for the same year.

This means that the retained profits which energize or weaken the operating capability of the firm exert different impacts on the company depending on which basis of measurement is followed at any given period of account. It follows therefore that the operating capabilities of the firm is energized or weakened by the method of profit measurement Millichamp (1989) reported, in a study carried out, that the historical cost profit reduces the operating capability of the firm during periods of rising prices while current cost profits energize the operating capability of the firm during period of rising prices. It follows from here that during periods of price recession, the historical cost profits energize the operating ability of the firm while current cost profits weaken it.

The amount charged on the profit as tax, calculated as depreciation and paid out as dividends greatly influence the operating strength of the firm. The operating strength of the company is enhanced by the relevance attached to the amount taken out of the profit as taxes, depreciation and dividends.

The differences in the bases of profit measurement become very prominent during periods of price changes where the value of today's Naira cannot be reasonably compared with the value of the Naira tomorrow. This rapid eroding effect on the purchasing power of the currency exerts equal and proportionate effect on the firm's operating ability. If profits are measured in a way that the figures are not overstated, the real value of the operating capability of the firm will be maintained.

\section{References}

Baran, A. (1996). Empirical investigation of general purchasing power adjustments on earnings. Journal of Accounting Research, 10, 112-115.

Barton, A. D. (1994). Expectations and Achievements in Income Theory. Accounting Review, 13, 65 - 71.

Berliner, R. W. (1993). Do analysts use inflation-adjusted information: Results of a survey. Economic Consequences of Financial Standards Selected Papers, 13, 7 - 10.

Bromwick, M. (1995). The general validity of certain current value asset valuation basis. Accounting Research, 5, $10-$ 15.

Davidson, S., Sticknay, C. P. \& Weil, R. L. (1996). Inflation Accounting: A Guide for the accountant and Financial Analysts. New York: McGraw Hill. 
Dean, G. A. (1994). The Stock of Fixed Capital in United Kingdom in 1991. Journal of the Royal Statistical Society, 127 (3), 142 - 146.

Federal Office of Statistics (2005). Wages, Income and Consumption. Abuja: Government Press.

Glautier, M. W. \& Underdown, E. (1998). Accounting theory and practice ( $3^{\text {rd }}$ edition). London: Pitman.

Gupta, S. P. (2002). Statistical Methods. New Delhi: Sultan Chand.

Hendrickson, E. S. \& Brenda, M. F. (1992). Accounting Theory (5 $5^{\text {th }}$ edition). London: Richard Irwin.

International Financial Reporting Standards (2004). Financial reporting in hyper inflationary economy. Washington DC: World Bank.

Ijiri, Y. (1997). The foundations of accounting measurement. New Delhi: Prentice Hall.

Kistner, K. P. \& Salmi, M. (1980). Holding gains and long-term liabilities. Accounting and Business Review, 21, (2), 21-27.

Millichamp, A. H. (1989). Foundation accounting: An instructional manual for accounting students. London: The Guarnsey Press.

Peterson, R. J. (1997). Impact of price-level accounting. The Accounting Review, 6 (1), 15 - 18.

Salvary, U. V. (2004). Measurement of portfolio performance under certainty. The American Economic Review, 15 (1), $12-17$

Table 1. Analysis of variability in methods of profit measurement on the operating capability of companies.

\begin{tabular}{|lcccc|}
\hline Level of & n & - & & \\
Measurement & 31 & 3627 & 2583 & \\
\hline Operating capital (C) & 31 & 711 & 3352 & \\
Historical profit (HP) & 31 & 56 & 4248 & \\
Current cost profit (CP) & 93 & & & \\
\hline TOTAL & SS & df & Ms & F \\
\hline Source of variation & 686 & 2 & 343 & \\
\hline Between samples & & & & $224^{*}$ \\
Within Samples & 431 & 90 & & \\
\hline Total & 1117 & 92 & & \\
\hline *Significant @ 0.05 level. $\mathrm{F}_{2}, 90=224, \mathrm{P}<0.05=2.99$ & & & \\
\hline
\end{tabular}

Table 2. Multiple regression analysis on the degree of influence of depreciation, taxes and dividends on the operating ability of the companies.

\begin{tabular}{|lccccccc|}
\hline $\begin{array}{l}\text { Bases of } \\
\text { Accounts }\end{array}$ & $\mathbf{a}_{\mathbf{O}}$ & bDEP & BTAX & bDIV & $\mathbf{t}$ & $\mathbf{r}$ & $\mathbf{t}_{\mathbf{r}} \mathbf{H C}$ \\
\hline Historical cost & -149803 & -5.86 & 0.438 & 8.631 & 29.12 & 0.91 & \\
& & & & & & & 0.82 \\
& & & & & & \\
Current cost & 972240 & 1.398 & 4.105 & 2.456 & 13.04 & 0.72 & $26.77^{*}$ \\
\hline * Significant @ & 0.05 level. & $\mathrm{t}_{60}=26.77:$ & $\mathrm{P}<$ & $0.05=$ & & \\
\hline
\end{tabular}

